\title{
The effects of Lactobacillus buchneri with or without a homolactic bacterium on the fermentation and aerobic stability of corn silages made at different locations
}

\author{
R. J. Schmidt and L. Kung Jr. ${ }^{1}$ \\ Department of Animal and Food Sciences, University of Delaware, Newark 19716
}

\begin{abstract}
Whole-plant corn (31 to $39 \%$ dry matter) from several locations was chopped, treated with nothing (U), Lactobacillus buchneri $40788\left(4 \times 10^{5} \mathrm{cfu} / \mathrm{g}\right.$; LB), or $L$. buchneri $\left(4 \times 10^{5} \mathrm{cfu} / \mathrm{g}\right)$ and Pediococcus pentosaceus $\left(1 \times 10^{5} \mathrm{cfu} / \mathrm{g} ; \mathrm{LBPP}\right)$, and packed into quadruplicate 20-L silos to determine their effects on silage fermentation and aerobic stability after $120 \mathrm{~d}$ of storage. The experiment was a randomized complete block design with main effects of treatment (T), block (location; L), and $\mathrm{T} \times \mathrm{L}$ interaction. Dry matter recovery was different among locations but unaffected by $\mathrm{T}$. The population of lactic acid bacteria was greater in LB and LBPP than in $\mathrm{U}$, and the opposite was true regarding the population of yeasts. Numbers of L. buchneri (colonyforming unit equivalents), determined by a real-time quantitative polymerase chain reaction, were higher in 4 of 5 locations for LB and LBPP compared with U $(\mathrm{T} \times \mathrm{L}$ interaction) with an average $6.70 \mathrm{log} \mathrm{cfu} / \mathrm{g}$ for LB and LBPP versus $4.87 \mathrm{log} \mathrm{cfu} / \mathrm{g}$ for U. Silages inoculated with LB and LBPP had higher silage $\mathrm{pH}$ and higher concentrations of acetic acid and 1,2 propanediol but lower concentrations of ethanol and water-soluble carbohydrates; there was a $\mathrm{T} \times \mathrm{L}$ interaction for all these variables. Aerobic stability was improved by LB and LBPP (mean of $136 \mathrm{~h}$ ) compared with U (44 h), but there was an interaction between $\mathrm{T} \times \mathrm{L}$. In general, locations with the highest population of L. buchneri had the largest increases in acetic acid and, consequently, the greatest improvements in aerobic stability. The addition of L. buchneri 40788 alone or with P. pentosaceus resulted in similar effects on silage fermentation and aerobic stability, but the effects were variable among locations, suggesting that unidentified factors; for example, in the field or on the forage crop, may alter the effectiveness of microbial inoculation.
\end{abstract}

Received July 8, 2009.

Accepted December 10, 2009.

${ }^{1}$ Corresponding author: lksilage@udel.edu
Key words: corn silage, Lactobacillus buchneri, realtime quantitative PCR

\section{INTRODUCTION}

Silage is the product resulting from the anaerobic fermentation of water-soluble carbohydrates to organic acids in forage crops. Lactic acid bacteria usually dominate the ensiling process and produce lactic acid, but fermentation is also dependent on a variety of other epiphytic microbes (many of which are detrimental; McDonald et al., 1991). Hence, the use of microbial inoculants is a recommended practice. Traditional inoculants, which normally contain species of classical homofermentative lactic acid bacteria, often claim to promote a faster fermentation, shifting the endproducts toward lactic acid and away from ethanol and acetic acid, therefore preserving nutrients by inhibiting plant enzymes and detrimental microorganisms. Even though these inoculants contain different microbes that were tested under varying conditions, Kung and Muck (1997) reported improved DM recovery and animal performance to homolactic inoculation by 2 to 3 and 3 to $5 \%$, respectively, in a summary of studies conducted between 1990 and 1995. However, homolactic acid inoculants have also been responsible for reductions in aerobic stability or the bunk life of some silage because of insufficient production of VFA that have antifungal activity (Weinberg et al., 1993; Kleinschmit et al., 2005).

Aerobic stability is of great importance because of the consequent losses of nutrients and DM and the potential development of molds having the potential to produce mycotoxins, which can pose health hazards to animals and humans (Driehuis and Oude Elferink, 2000). Upon exposure to air, lactate-assimilating yeasts initiate the spoilage process in silage, metabolizing lactic acid into carbon dioxide and water (Woolford, 1990). Consequently, $\mathrm{pH}$ increases and other opportunistic aerobic microbes such as molds and some bacteria proliferate and further aggravate the spoilage in the silage mass (Pahlow et al., 2003). Specifically, silages of corn and small grains are very sensitive to aerobic deterioration 
because of the high concentration of substrates such as organic acids and starch, which are utilized by undesirable microorganisms (Kung and Ranjit, 2001; Muck, 2004).

Among the additives aiming to improve aerobic stability of silages, Lactobacillus buchneri is a good alternative to buffered propionic acid-based products, because it has been proven to deliver effects similar to those of the chemical additives and, moreover, it is safer (nonhazardous, noncorrosive) and more economically competitive (Bolsen et al., 1992b). A meta-analysis showed that inoculation with L. buchneri enhances aerobic stability in a variety of forage crops (Kleinschmit and Kung, 2006b). However, in a previous research study evaluating the effectiveness of L. buchneri with Pediococcus pentosaceus, the aerobic stability of corn silage was not consistently improved (Kleinschmit and Kung, 2006a). Therefore, the objective of this experiment was to investigate the population dynamics and effectiveness of L. buchneri alone or in combination with $P$. pentosaceus on fermentation products, microbial populations, and aerobic stability of corn silages. A second objective was to evaluate the repeatability of the inoculant's effectiveness when harvested from different locations. Our hypothesis was that there might be potential antagonistic effects from combining $L$. buchneri with $P$. pentosaceus and that there may be unknown site-specific conditions that affect the response to inoculation.

\section{MATERIALS AND METHODS}

\section{Forages and Ensiling}

Whole-plant corn obtained from several locations (blocks; A to E) was harvested and chopped to a theoretical length of $1.9 \mathrm{~cm}$. The following cultivars were obtained from the University of Delaware Dairy in Newark: A) Pioneer 33B51 (Pioneer Hi-Bred International Inc., Johnston, IA), at 40\% DM; B) Pioneer 33B51, at 31\% DM; and C) Mycogen F2F797 (a brown mid-rib hybrid, Mycogen Seeds, Indianapolis, IN), at $32 \%$ DM, where a New Holland FP 230 pull-type forage harvester equipped with a mechanical processor (New Holland, PA) was used for chopping. From the New Bolton Center at the University of Pennsylvania in Kennett Square, the following corn hybrids were used: D) Golden Harvest Ex-39291 (Golden Harvest Seeds Inc., Waterloo, NE) at 32\% DM; and E) Masters Choice MC-615 (Masters Choice Inc., Anna, IL), at $35 \%$ DM. At that location, a New Holland FP 240 pull-type harvester equipped with an on-board kernel processor (New Holland, PA) was used for chopping the forage.
Within 30 min of harvesting, chopped corn of each cultivar was divided into three $75-\mathrm{kg}$ piles. Each pile was assigned to one of the following treatments: deionized water, untreated (U); L. buchneri NCIMB 40788, applied at $4 \times 10^{5} \mathrm{cfu} / \mathrm{g}$ of fresh corn (Lallemand Animal Nutrition, Milwaukee, WI; LB); and L. buchneri NCIMB 40788 and P. pentosaceus NCIMB 12455, applied at $4 \times 10^{5}$ and $1 \times 10^{5} \mathrm{cfu} / \mathrm{g}$ of fresh corn, respectively (Lallemand Animal Nutrition; LBPP). All treatments were dissolved in $500 \mathrm{~mL}$ of deionized water and sprayed on the forages uniformly and under constant mixing.

Treated forages were packed into four 20-L experimental silos ( $30 \mathrm{~cm}$ diameter $\times 36 \mathrm{~cm}$ height) per treatment at a packing density of $232 \pm 15 \mathrm{~kg}$ of $\mathrm{DM} / \mathrm{m}^{3}$ $\left(14.5 \pm 0.9 \mathrm{lb} / \mathrm{ft}^{3}\right)$. Silos were sealed with 2 layers of polyethylene plastic and stored for $120 \mathrm{~d}$ in a closed barn at room temperature $\left(23 \pm 2^{\circ} \mathrm{C}\right)$. Triplicate samples of untreated fresh forage were collected before ensiling and frozen for later analysis. After the ensiling period the silos were weighed, their contents were thoroughly mixed, and random samples were taken for determination of fermentation profile, microbial population, DM recovery, and aerobic stability.

\section{Chemical and Microbial Analyses}

Dry matter content was determined by drying samples in a $60^{\circ} \mathrm{C}$ forced-air oven for $48 \mathrm{~h}$. Water extracts were prepared by adding $25 \mathrm{~g}$ of fresh forage to 225 $\mathrm{mL}$ of sterile $25 \%$ strength Ringer's solution (Oxoid BR52, Unipath, Basingstoke, UK) and homogenizing for $1 \mathrm{~min}$. The $\mathrm{pH}$ of the water extract was measured, and a portion of it was filtered through Whatman 54 filter paper (Clifton, NJ), acidified with $50 \% \mathrm{H}_{2} \mathrm{SO}_{4}$ to reduce the $\mathrm{pH}$ of the extract to $<2.0$, and frozen before analysis for ammonia-N (Weatherburn, 1967) and water-soluble carbohydrates (WSC) (Nelson, 1944).

Another portion of the water extracts was filtered through a double layer of cheesecloth into 2 sets of sterile tubes for microbial analyses. One set was immediately frozen for later extraction of bacterial DNA. The second set was used for enumeration of lactic acid bacteria by pour plating 10-fold serial dilutions on de Man, Rogosa, and Sharpe agar (MRS; Oxoid CM0361), and for the population of yeasts and molds by pour plating on malt extract agar (Oxoid CM0059) that had been acidified with $85 \%$ lactic acid $(0.5 \% \mathrm{vol} / \mathrm{vol})$ after autoclaving. A 1-mL aliquot was collected from the spray bottles before inoculation and also pour-plated on MRS agar to confirm the targeted application rate of the inoculants. Agar plates were incubated in a $32^{\circ} \mathrm{C}$ oven for 48 to $72 \mathrm{~h}$ and counted for numbers of viable colony-forming units. 
In addition, the water extracts made from the silage samples were analyzed for VFA, 1,2-propanediol $(\mathbf{1 , 2}$ PD), lactic acid, and ethanol with a high-performance liquid chromatograph (Shimadzu SCL-10 AVP, Shimadzu Scientific Instruments, Columbia, MD) equipped with a refractive index detector (RID-10A; Dairyland Laboratories, Arcadia, WI), according to Muck and Dickerson (1988).

Both microbial inoculants were plated on MRS agar before use and appropriate amounts were used to meet the targeted application rates. To potentially explain why inoculation was not equally effective across all locations, an agar spot assay (Chopin et al., 1976) for phage infection against $L$. buchneri was performed. In that assay, $200 \mu \mathrm{L}$ of $L$. buchneri 40788 at log phase (optical density of approximately 0.2 at $600 \mathrm{~nm}$ ) was added to $3 \mathrm{~mL}$ of MRS soft agar $(0.35 \%$ of agar with 10 $\mathrm{m} M$ of glycine) at $45^{\circ} \mathrm{C}$ and poured onto an MRS agar plate. After solidification of the soft agar, $2 \mu \mathrm{L}$ of silage extracts sterilized by membrane filtration (pore size, $0.45 \mu \mathrm{m}$ ) and a positive control were spotted onto the agar. The plates were incubated overnight at $30^{\circ} \mathrm{C}$, and phage infection was indicated by a zone of clearance in the soft agar layer.

The recovery of DM after ensiling was calculated according to weight differences between the silos and DM concentrations of the fresh and ensiled material.

The aerobic stability of the silages was determined by exposing $3 \mathrm{~kg}$ of silage samples in 20-L silos to air for $10 \mathrm{~d}$ in a room with temperatures between 23 and $25^{\circ} \mathrm{C}$. A thermocouple wire, inserted in the middle of the silage mass, was attached to a data logger (model number CR10X, Campbell Scientific Inc., Logan, UT) that recorded the temperature every $10 \mathrm{~min}$ and averaged these values every $2 \mathrm{~h}$. The silos were covered with a layer of cheesecloth to allow air to infiltrate the silage mass and prevent the silage from drying out and from contamination. Aerobic stability was defined as the number of hours the silage remained stable before a $2^{\circ} \mathrm{C}$ increase relative to ambient temperature (Kung and Ranjit, 2001).

Bacterial DNA was extracted according to Schmidt et al. (2008) and served as template for real-time quantitative PCR using the primer pair specific for $L$. buchneri 186-LBF2 (5'-GAAACAGGTGCTAATACCGTATAACAACCA-3') and 316-LBR1 (5'-CGCCTTGGTAGGCCGTTACCTTACCAACA-3'). Samples were run in a 7900HT Fast Real-time PCR System (Applied Biosystems, Foster City, CA), with the following conditions: $95^{\circ} \mathrm{C}$ for $30 \mathrm{~s}, 61^{\circ} \mathrm{C}$ for $30 \mathrm{~s}$, and $56^{\circ} \mathrm{C}$ for 30 $\mathrm{s}$ for 40 cycles. The reaction mixture contained $12 \mu \mathrm{L}$ of SYBR Green PCR Master Mix (Applied Biosystems), $2 \mu \mathrm{L}$ of DNA, and $100 \mathrm{nM}$ of each primer diluted in 5 $\mu \mathrm{L}$ of $\mathrm{H}_{2} \mathrm{O}$. The amplification products were visualized using the software Sequence Detector 1.7 from the ABI Prism 7900 system (Applied Biosystems). The standard curve was constructed using Microsoft Excel 2000 by plotting the number of input cells against the cycle threshold $\left(C_{T}\right)$ value.

Noninoculated corn silage from a bunker silo at the University of Pennsylvania (Kennett Square) was used for the construction of standards to quantify $L$. buchneri. Five kilograms of silage were artificially inoculated with L. buchneri 40788 (Lallemand Animal Nutrition) to obtain a range of $10^{3}, 10^{4}, 10^{5}, 10^{6}, 10^{7}$, and $10^{8} \mathrm{cfu} / \mathrm{g}$ of silage. The counts of L. buchneri were determined beforehand by pour plating on MRS agar. Within an hour from the sampling time, water extracts were obtained as described previously for later isolation of DNA. Numbers of L. buchneri are presented as cfu equivalents (cfu-e) because detected bacterial DNA can come from viable or dead bacteria.

\section{Statistical Analysis}

All microbial data was transformed to $\log _{10}$ and are presented on a wet weight basis. Chemical data are presented on a DM basis. Statistical analyses were performed using the GLM and CORR procedures of SAS (SAS Institute, 1998) for a randomized complete block design. Data were analyzed using the model

$$
\mathrm{Y}_{\mathrm{ijk}}=\mu+\mathrm{T}_{\mathrm{i}}+\mathrm{L}_{\mathrm{j}}+(\mathrm{TL})_{\mathrm{ij}}+\mathrm{e}_{\mathrm{ijk}},
$$

where $Y_{\mathrm{ijk}}=$ dependent variable representing the response for the treatment $\mathrm{i}$ observed in block $\mathrm{j} ; \mu=$ mean; $\mathrm{T}_{\mathrm{i}}=$ treatment (inoculant) effect; $\mathrm{L}_{\mathrm{j}}=$ block (location) effect; $(\mathrm{TL})_{\mathrm{ij}}=$ interaction; and $\mathrm{e}_{\mathrm{ij \textrm {k }}}=$ residual (error). Least squares means were used to test significant differences among treatments. Contrasts were constructed to evaluate the effects of treatments within the locations, and single degree-of-freedom orthogonal comparisons were $\mathrm{U}$ versus $\mathrm{LB}+\mathrm{LBPP}$ and LB versus LBPP. Significance was defined at $P<0.05$, whereas trends toward a significant effect were noted when $0.05 \leq P \leq 0.10$.

\section{RESULTS}

The chemical and microbial compositions of fresh chopped forage from all locations are shown in Table 1. The DM content of the fresh forages ranged from 31.4 to $40 \%$. The $\mathrm{pH}$ and concentration of $\mathrm{NH}_{3}-\mathrm{N}$ were within normal ranges for fresh corn (Ranjit and Kung, 2000; Kleinschmit and Kung, 2006b). The concentration of WSC was sufficient to ensure adequate ensiling, ranging from $4.92 \%$ (C) to $7.57 \%$ (B). The numbers of 
Table 1. Chemical (DM basis) and microbial composition (wet basis) of fresh whole-plant corn from 5 different locations before ensiling

\begin{tabular}{lcccccc}
\hline & \multicolumn{5}{c}{ Location } & \\
\cline { 2 - 5 } Item & $\mathrm{A}$ & $\mathrm{B}$ & $\mathrm{C}$ & $\mathrm{D}$ & $\mathrm{E}$ & SEM \\
\hline $\mathrm{DM}, \%$ & $39.98^{\mathrm{a}}$ & $31.37^{\mathrm{c}}$ & $31.67^{\mathrm{c}}$ & $31.42^{\mathrm{c}}$ & $35.33^{\mathrm{b}}$ & 0.42 \\
$\mathrm{pH}$ & $5.52^{\mathrm{ab}}$ & $5.47^{\mathrm{b}}$ & $5.32^{\mathrm{b}}$ & $5.34^{\mathrm{b}}$ & $5.68^{\mathrm{a}}$ & 0.07 \\
$\mathrm{NH}_{3}-\mathrm{N}, \%$ & $0.029^{\mathrm{d}}$ & $0.058^{\mathrm{b}}$ & $0.043^{\mathrm{c}}$ & $0.068^{\mathrm{a}}$ & $0.023^{\mathrm{d}}$ & 0.003 \\
$\mathrm{WSC}^{1} \%$ & $6.45^{\mathrm{b}}$ & $7.57^{\mathrm{a}}$ & $4.92^{\mathrm{c}}$ & $6.93^{\mathrm{ab}}$ & $6.00^{\mathrm{b}}$ & 0.35 \\
$\mathrm{LAB},{ }^{\mathrm{b}} \log \mathrm{cfu} / \mathrm{g}$ & $7.63^{\mathrm{c}}$ & $8.09^{\mathrm{b}}$ & $8.47^{\mathrm{a}}$ & $8.44^{\mathrm{a}}$ & $6.87^{\mathrm{d}}$ & 0.13 \\
Yeasts, log cfu/g & $5.69^{\mathrm{d}}$ & $5.92^{\text {cd }}$ & $7.03^{\mathrm{b}}$ & $7.47^{\mathrm{a}}$ & $6.21^{\mathrm{c}}$ & 0.11 \\
Molds, log cfu/g & $5.05^{\mathrm{d}}$ & $5.03^{\mathrm{d}}$ & $6.00^{\mathrm{b}}$ & $6.29^{\mathrm{a}}$ & $5.64^{\mathrm{c}}$ & 0.09 \\
\hline
\end{tabular}

${ }^{\mathrm{a}-\mathrm{d}}$ Means within a row with unlike superscripts differ $(P<0.05)$.

${ }^{1}$ Water-soluble carbohydrates.

${ }^{2}$ Lactic acid bacteria.

epiphytic LAB were higher than $8 \mathrm{log} \mathrm{cfu} / \mathrm{g}$ of forage from locations $\mathrm{B}, \mathrm{C}$, and $\mathrm{D}$, whereas that in forage from $\mathrm{A}$ and $\mathrm{E}$ had 7.63 and $6.87 \mathrm{log} \mathrm{cfu} / \mathrm{g}$, respectively. Locations $\mathrm{C}$ and $\mathrm{D}$ also had more yeasts (more than 7 $\log \mathrm{cfu} / \mathrm{g}$ ) and molds (more than $6 \log \mathrm{cfu} / \mathrm{g}$ ) in corn plants. Estimated numbers of L. buchneri (cfu-e) in fresh corn from all locations were within the qualitative determination but slightly under the range of quantitative determination of our real-time quantitative PCR assay, which was between 2 and $3 \log \mathrm{cfu} / \mathrm{g}$; thus, these data are not shown.

The main effects of treatment and location on the chemical and microbial composition of the corn silages after $120 \mathrm{~d}$ of fermentation are shown in Table 2. There were no effects of inoculation on DM recovery or on concentrations of $\mathrm{DM}$ and $\mathrm{NH}_{3}-\mathrm{N}$. There were, however, differences among locations for these variables. Numbers of LAB were markedly higher and numbers of yeasts were markedly lower in inoculated silages compared with untreated silage; the numbers of LAB and yeasts also varied by location. There were interactions between treatment and location for all other variables.

Table 3 shows the effects of inoculation on the $\mathrm{pH}$ and concentrations of lactic and acetic acid and aerobic stability within the locations. (Propionic acid was not detected in any samples; data not shown.) In all locations, the $\mathrm{pH}$ of inoculated silages was greater than untreated silages and was not different between types of inoculation at locations A through D. However, there was a difference in $\mathrm{pH}$ between $\mathrm{LB}$ and LBPP at

Table 2. Effects of treatment and location on chemical (DM basis) and microbial (wet basis) composition and aerobic stability of corn silages after $120 \mathrm{~d}$ of ensiling

\begin{tabular}{|c|c|c|c|c|c|c|c|c|c|c|c|c|c|}
\hline Item & \multicolumn{3}{|c|}{ Treatment $^{1}(\mathrm{~T})$} & $\mathrm{SE}$ & \multicolumn{5}{|c|}{ Location $^{2}(\mathrm{~L})$} & $\mathrm{SE}$ & \multicolumn{3}{|c|}{ Effect, $P$-value } \\
\hline DM recovery, \% & 96.85 & 96.74 & 97.17 & 0.66 & $96.37^{\mathrm{b}}$ & $99.36^{\mathrm{a}}$ & $96.01^{\mathrm{b}}$ & $96.81^{\mathrm{b}}$ & $96.04^{\mathrm{b}}$ & 0.96 & NS & $* *$ & NS \\
\hline $\mathrm{pH}$ & $3.61^{\mathrm{b}}$ & $3.69^{\mathrm{a}}$ & $3.68^{\mathrm{a}}$ & 0.01 & $3.62^{\mathrm{c}}$ & $3.59^{\mathrm{d}}$ & $3.68^{\mathrm{b}}$ & $3.67^{\mathrm{b}}$ & $3.75^{\mathrm{a}}$ & 0.01 & $* *$ & $* *$ & $* *$ \\
\hline Lactic acid, \% & $5.73^{\mathrm{a}}$ & $5.32^{\mathrm{b}}$ & $5.44^{\mathrm{ab}}$ & 0.10 & $4.68^{\mathrm{c}}$ & $6.13^{\mathrm{b}}$ & $6.02^{\mathrm{b}}$ & $6.57^{\mathrm{a}}$ & $4.09^{\mathrm{d}}$ & 0.15 & $* *$ & ** & ** \\
\hline Acetic acid, \% & $1.23^{\mathrm{b}}$ & $1.95^{\mathrm{a}}$ & $1.80^{\mathrm{a}}$ & 0.05 & $1.05^{\mathrm{e}}$ & $1.38^{\mathrm{d}}$ & $1.58^{\mathrm{c}}$ & $1.97^{\mathrm{b}}$ & $2.32^{\mathrm{a}}$ & 0.08 & ** & ** & ** \\
\hline $\mathrm{NH}_{3}-\mathrm{N}, \%$ & 0.094 & 0.096 & 0.098 & 0.002 & $0.093^{\mathrm{c}}$ & $0.101^{\mathrm{c}}$ & $0.110^{\mathrm{b}}$ & $0.124^{\mathrm{a}}$ & $0.052^{\mathrm{d}}$ & 0.003 & NS & $* *$ & NS \\
\hline Water-soluble carbohydrates, \% & $1.09^{\mathrm{a}}$ & $0.79^{\mathrm{b}}$ & $0.76^{\mathrm{b}}$ & 0.03 & $0.58^{\mathrm{c}}$ & $0.97^{\mathrm{a}}$ & $1.04^{\mathrm{a}}$ & $0.98^{\mathrm{a}}$ & $0.82^{\mathrm{b}}$ & 0.04 & $* *$ & ** & ** \\
\hline Lactic acid bacteria, log cfu/g & $5.72^{\mathrm{b}}$ & $8.32^{\mathrm{a}}$ & $8.21^{\mathrm{a}}$ & 0.10 & $7.04^{\mathrm{b}}$ & $7.00^{\mathrm{b}}$ & $6.98^{\mathrm{b}}$ & $7.94^{\mathrm{a}}$ & $8.12^{\mathrm{a}}$ & 0.14 & ** & ** & NS \\
\hline L. buchneri, log cfu-e $\mathrm{e}^{3} / \mathrm{g}$ & $4.87^{\mathrm{b}}$ & $6.88^{\mathrm{a}}$ & $6.64^{\mathrm{a}}$ & 0.22 & $5.04^{\mathrm{c}}$ & $6.33^{\mathrm{ab}}$ & $6.25^{\mathrm{ab}}$ & $5.98^{\mathrm{b}}$ & $7.05^{\mathrm{a}}$ & 0.28 & $* *$ & $* *$ & $*$ \\
\hline Yeasts, $\log \mathrm{cfu} / \mathrm{g}$ & $4.39^{\mathrm{a}}$ & $2.42^{\mathrm{b}}$ & $2.65^{\mathrm{b}}$ & 0.36 & $3.21^{\mathrm{ab}}$ & $4.38^{\mathrm{a}}$ & $2.49^{\mathrm{b}}$ & $3.30^{\mathrm{ab}}$ & $2.39^{\mathrm{b}}$ & 0.52 & $* *$ & $* *$ & NS \\
\hline Molds, log cfu/g & $2.92^{\mathrm{a}}$ & $1.25^{\mathrm{b}}$ & $1.96^{\mathrm{b}}$ & 0.26 & $3.83^{\mathrm{a}}$ & $2.09^{\mathrm{b}}$ & $2.30^{\mathrm{b}}$ & $2.00^{\mathrm{b}}$ & $0.00^{\mathrm{c}}$ & 0.38 & $* *$ & $* *$ & $* *$ \\
\hline Aerobic stability, h & $44^{\mathrm{b}}$ & $136^{\mathrm{a}}$ & $136^{\mathrm{a}}$ & 7.56 & $56^{\mathrm{c}}$ & $57^{\mathrm{c}}$ & $99^{c}$ & $144^{\mathrm{b}}$ & $171^{\mathrm{a}}$ & 10.91 & $* *$ & $* *$ & $* *$ \\
\hline
\end{tabular}

${ }^{\mathrm{a}-\mathrm{d}}$ Means in rows within treatment or within location with unlike superscripts differ.

${ }^{1} \mathrm{U}=$ untreated; $\mathrm{LB}=$ Lactobacillus buchneri 40788 added to achieve a final application rate of $4 \times 10^{5} \mathrm{cfu} / \mathrm{g}$ of corn; LBPP $=$ L. buchneri 40788 and Pediococcus pentosaceus added to achieve a final application rate of $4 \times 10^{5} \mathrm{cfu} / \mathrm{g}$ and $1 \times 10^{5} \mathrm{cfu} / \mathrm{g}$ of corn, respectively.

${ }^{2}$ Letters correspond to 5 locations.

${ }^{3}$ Colony-forming units-equivalent.

$\mathrm{NS}=P>0.10 ; * 0.05 \leq P<0.10 ; * * P<0.05$. 
Table 3. Effects of inoculation on $\mathrm{pH}$, concentration of lactic acid and acetic acid (DM basis) and aerobic stability in corn silages at different locations after $120 \mathrm{~d}$ of ensiling

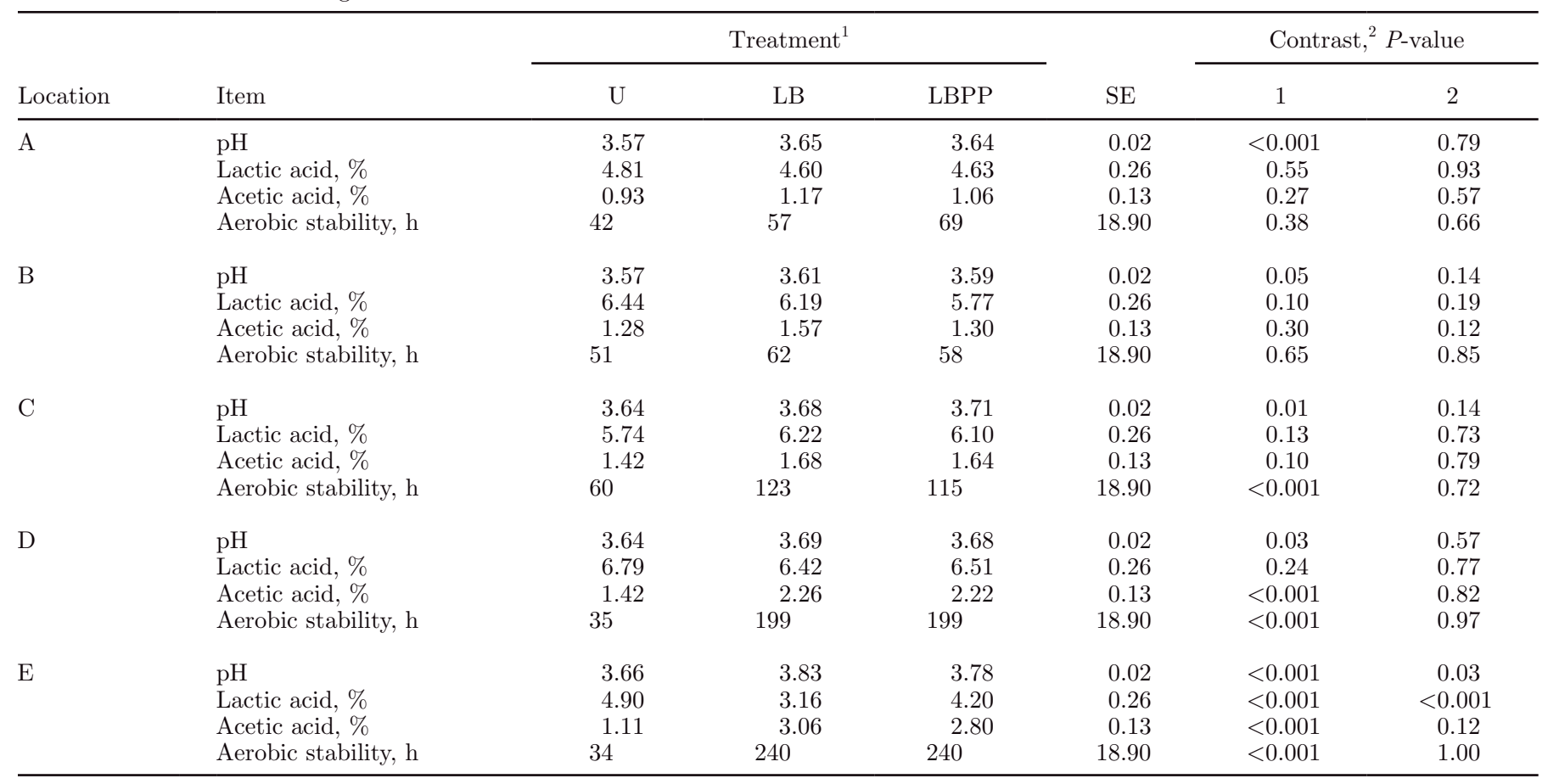

${ }^{1} \mathrm{U}=$ untreated; $\mathrm{LB}=$ Lactobacillus buchneri 40788 added to achieve a final application rate of $4 \times 10^{5}$ cfu/g of corn; LBPP $=$ L. buchneri 40788 and Pediococcus pentosaceus added to achieve a final application rate of $4 \times 10^{5} \mathrm{cfu} / \mathrm{g}$ and $1 \times 10^{5} \mathrm{cfu} / \mathrm{g}$ of corn, respectively.

${ }^{2} 1=\mathrm{U}$ vs. LB $+\mathrm{LBPP} ; 2=\mathrm{LB}$ vs. LBPP.

location E. Lactic acid was unaffected by inoculation at locations $\mathrm{A}$ through $\mathrm{D}$ but was lower in inoculated silages compared with untreated silage and lower in LB compared with LBPP treated silage at location E. Acetic acid concentration and aerobic stability were higher or tended to be higher in inoculated silages at locations $\mathrm{C}, \mathrm{D}$, and E.

The concentrations of 1,2-PD, ethanol, and WSC by location and treatment are shown in Table 4 . Inoculation increased the concentration of 1,2-PD only at locations $\mathrm{D}$ and $\mathrm{E}$ and decreased the concentration of ethanol at locations B and E. Residual amounts of WSC were lower as a result of inoculation at locations $\mathrm{A}, \mathrm{B}$, and $\mathrm{E}$.

The numbers of various microbial populations are shown by location and treatment in Table 5. In all but one instance (fewer molds for LB than LBPP at location B), the effects due to inoculation were similar regardless of type of inoculation (LB vs. LBPP). Apparent numbers of $L$. buchneri were greater in inoculated silages compared with untreated silages at locations $\mathrm{A}, \mathrm{C}$, and $\mathrm{E}$ and tended to be greater $(P<0.07)$ at location B. There were numerically fewer yeasts in all inoculated silages compared with untreated silage at all locations but the effect was statistically different only at locations $\mathrm{D}$ and $\mathrm{E}$, where the differences were extremely marked. The numbers of molds were less in inoculated silages at locations B and D. There was no phage activity detected toward L. buchneri from any of the silages sampled (data not shown).

\section{DISCUSSION}

In the present study, silages inoculated with LB or LBPP had, in general, higher $\mathrm{pH}$ and higher concentrations of acetic acid, fewer yeasts and molds, and improved aerobic stability at locations C, D, and E but not at locations $\mathrm{A}$ and $\mathrm{B}$ when compared with untreated silage. Although inoculated silages at locations A and B had higher populations of lactic acid bacteria and L. buchneri (cfu-e), the magnitude of the response for L. buchneri at these locations was less than that observed at locations C, D, and E. In support of this finding, there were no effects of inoculation on the concentrations of 1,2-PD or acetic acid or on aerobic stability in locations A and B, which are usually found at higher levels in silages treated with $L$. buchneri than in untreated ones. Kleinschmit and Kung (2006a) also reported that corn silages inoculated with $L$. buchneri and $P$. pentosaceus had inconsistent improvements in aerobic stability, but inoculation consistently increased levels of acetic acid in those silages compared with 
Table 4. Effects of inoculation on the concentrations of 1,2-propanediol, ethanol, and water-soluble carbohydrates (WSC; DM basis) in corn silages at different locations after $120 \mathrm{~d}$ of ensiling

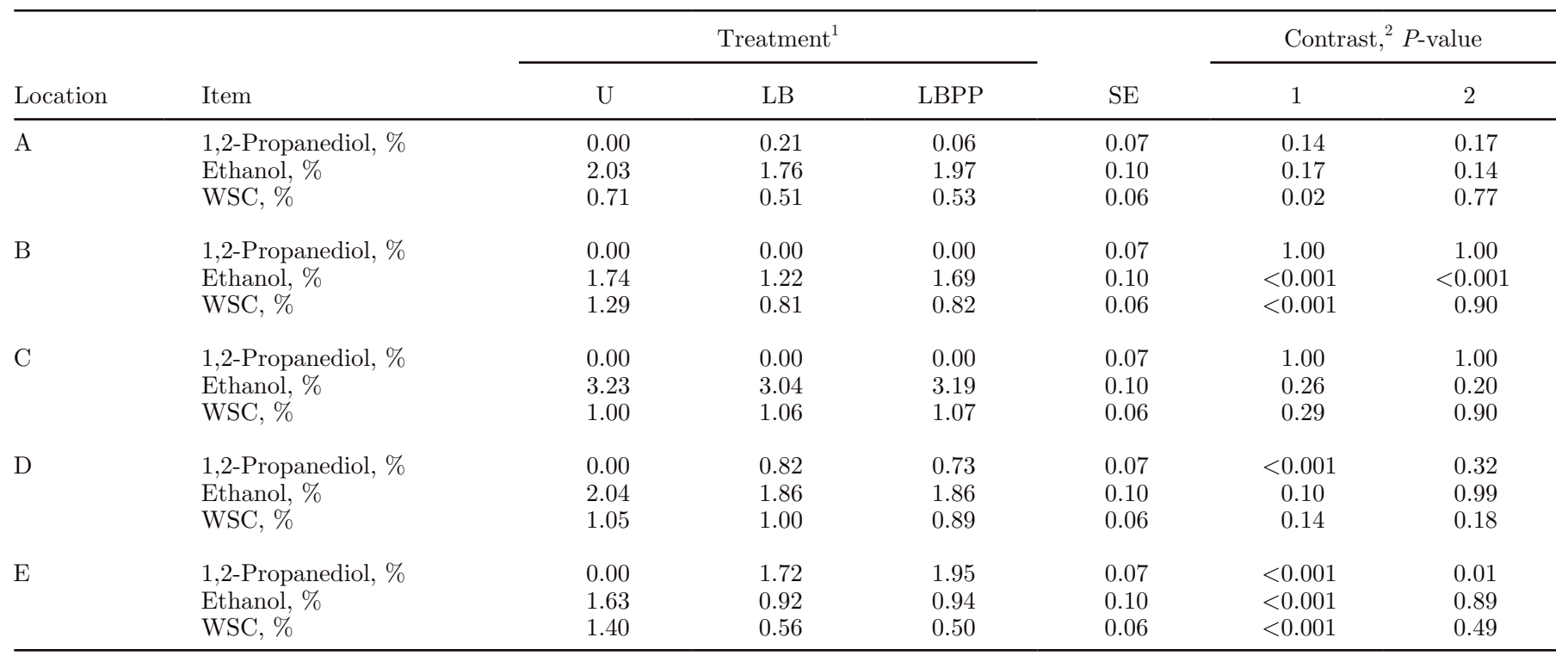

${ }^{1} \mathrm{U}=$ untreated; $\mathrm{LB}=$ Lactobacillus buchneri 40788 added to achieve a final application rate of $4 \times 10^{5} \mathrm{cfu} / \mathrm{g}$ of corn; LBPP $=$ L. buchneri 40788 and Pediococcus pentosaceus added to achieve a final application rate of $4 \times 10^{5} \mathrm{cfu} / \mathrm{g}$ and $1 \times 10^{5} \mathrm{cfu} / \mathrm{g}$ of corn, respectively.

${ }^{2} 1=\mathrm{U}$ vs. LB $+\mathrm{LBPP} ; 2=\mathrm{LB}$ vs. LBPP.

Table 5. Effects of inoculation on the microbial population of corn silages from different locations after $120 \mathrm{~d}$ of ensiling

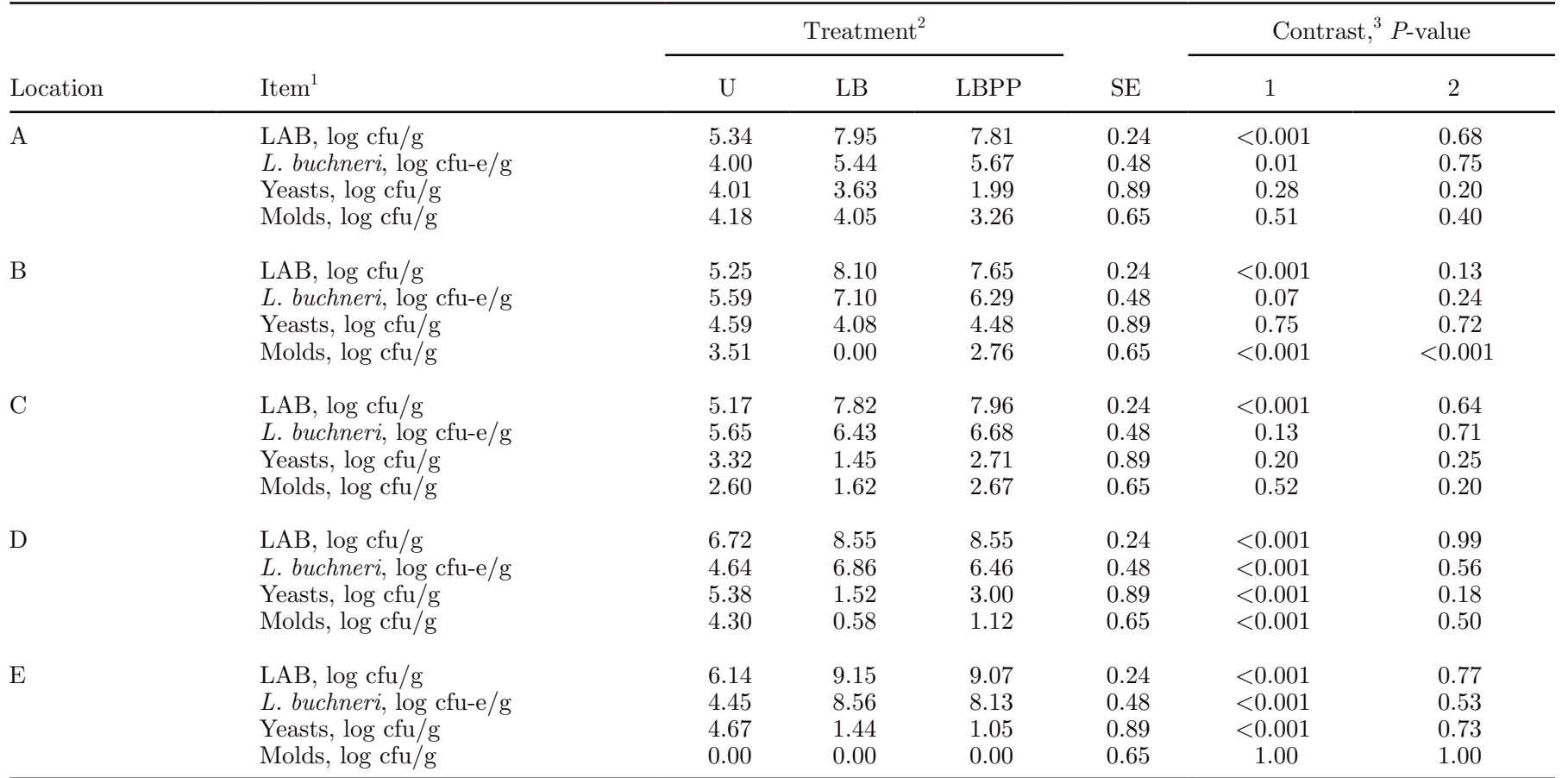

${ }^{1} \mathrm{LAB}=$ lactic acid bacteria; cfu-e = colony-forming units-equivalent.

${ }^{2} \mathrm{U}=$ untreated $\mathrm{LB}=$ Lactobacillus buchneri 40788 added to achieve a final application rate of $4 \times 10^{5}$ cfu $/ \mathrm{g}$ of corn; LBPP $=$ L. buchneri 40788 and Pediococcus pentosaceus added to achieve a final application rate of $4 \times 10^{5} \mathrm{cfu} / \mathrm{g}$ and $1 \times 10^{5} \mathrm{cfu} / \mathrm{g}$ of corn, respectively.

${ }^{3} 1=\mathrm{U}$ vs. LB $+\mathrm{LBPP} ; 2=\mathrm{LB}$ vs. LBPP. 


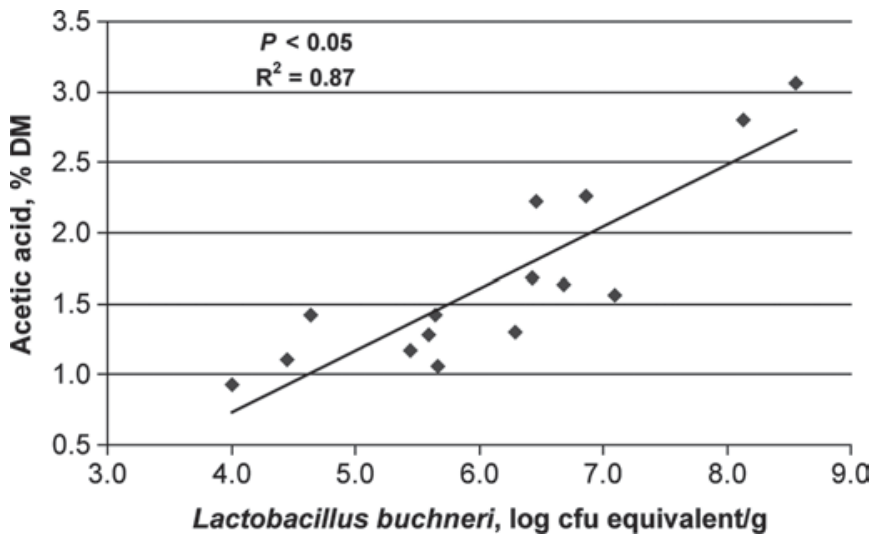

Figure 1. Relationship between the numbers of Lactobacillus buchneri and the concentrations of acetic acid (DM basis) in corn silages from different locations.

untreated silages, which differed from the results of our study. The findings from the current study suggest that substantial changes in fermentation end-products, yeasts, and aerobic stability occur when inoculation increases the population of L. buchneri by 2 log over the natural population of this organism. The high correlation between numbers of L. buchneri and concentration of acetic acid (Figure 1) and the high correlation between concentration of acetic acid and aerobic stability (Figure 2) further substantiate this finding. Pitt and Leibensperger (1987) suggested that the rate of application of a microbial inoculant ( $\mathrm{cfu} / \mathrm{g}$ of fresh forage) should at least equalize the epiphytic population to affect the fermentation profile of the silage. Similarly, Bolsen et al. (1992a) suggested that factors such as epiphytic microbial population, DM content, and WSC concentration from different locations, hybrid selection, or stage of maturity might influence the outcome of

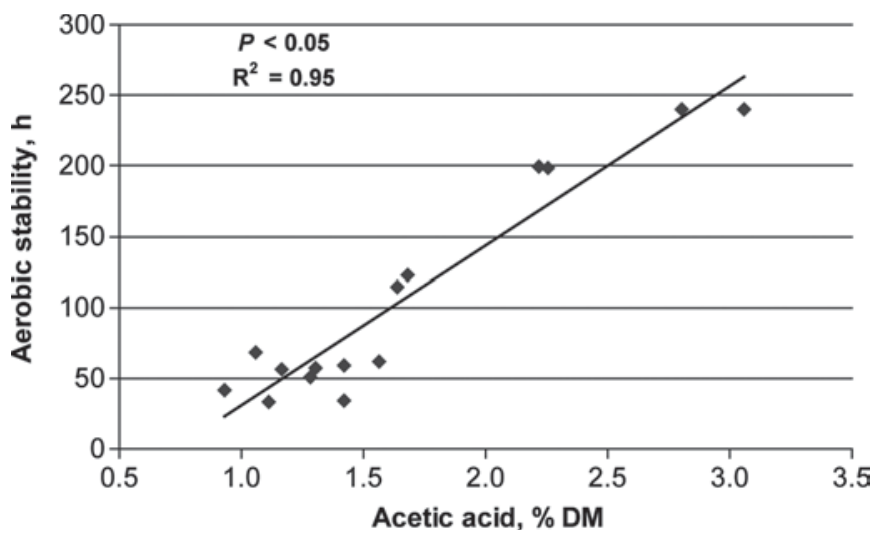

Figure 2. Relationship between the concentrations of acetic acid (DM basis) and the hours of aerobic stability in corn silages from different locations. inoculation in silages. We could not find any apparent relationships between the starting populations of microorganisms (Table 1) and the relative effectiveness of the inoculants on final silage fermentation in our study. However, the silages that did not show improvements in aerobic stability were made from the same hybrid (at locations A and B), which was different from that planted at the other locations. Differences in aerobic stability between cultivars of corn have been reported (Wyss, 2003) but the exact reasons for these differences are unknown.

To explain the variable effects of inoculation observed in our study, we hypothesized that bacteriophages against L. buchneri might have been present in the nonresponsive silages, because phages represent one of the main causes of fermentation failure in the dairy industry (Mäyrä-MäKinen and Bigret, 1993). However, no phage activity against $L$. buchneri was detected in any of the silages in our study.

Only minor differences were detected in some of the variables measured between silages treated with LB alone versus LBPP. Weinberg et al. (2002) studied a combination of Lactobacillus plantarum and L. buchneri in corn and wheat silages, and the effects of L. buchneri were not as clear, particularly in corn silage, based on the fermentation products and the presence of molds. Nevertheless, L. buchneri improved the aerobic stability of the silages based on $\mathrm{CO}_{2}$ production, yeast population, and $\mathrm{pH}$, regardless of whether it was applied alone or with L. plantarum. Driehuis et al. (2001) evaluated the effects of inoculation with $L$. buchneri alone or in combination with L. plantarum and $P$. pentosaceus in grass silages, and the addition of the homolactic bacteria resulted in less protein degradation and lower DM losses without diminishing the improvements in aerobic stability. The losses in DM can be useful to measure the heterofermentative activity of $L$. buchneri, but no trends were observed in the present study. Lower DM recovery in silages treated with $L$. buchneri has been reported by some researchers (Driehuis et al., 1999, 2001) but not others (Ranjit et al., 2002).

Although inoculation with traditional homolactic acid bacteria has sometimes made aerobic stability worse (Weinberg et al., 1993; Filya, 2003), this phenomenon was not observed in silages treated with LBPP in our study, possibly because this potential worsening in aerobic stability was counteracted by the effects of L. buchneri. Similar results were reported by Driehuis et al. (2001), who inoculated L. buchneri with and without a mixture of homolactic bacteria (L. plantarum and $P$. pentosaceus) in grass silages. The reason for the expected enhancement in aerobic stability of silages inoculated with $L$. buchneri is the inhibition of yeasts by the production of acetic acid (Driehuis et al., 
1999). It has been shown that L. buchneri is stimulated by the low $\mathrm{pH}$ of silages after the active phase of fermentation and, under anaerobic conditions, is able to convert moderate amounts of lactic acid into equal parts of acetic acid and 1,2-PD and traces of ethanol and $\mathrm{CO}_{2}$ (Oude Elferink et al., 2001). Acetic acid has been reported as a potent inhibitor of fungi (Moon, 1983), which play an active role in aerobic deterioration (McDonald et al., 1991), but 1,2-PD has no effects on fungi (Danner et al., 2003). In some silages it has been reported that 1,2-PD can be partially converted to propionic acid by Lactobacillus diolivorans (Krooneman et al., 2002). Propionic acid is also a strong antimycotic agent, but that metabolite was not detected in the present study, and even the presence of 1,2-PD was not consistent in the silages from all the different locations. This relationship between the content of acetic acid and the aerobic stability of our samples is in agreement with the results of Danner et al. (2003), who reported a correlation value of almost 1.0.

The antimicrobial effect of an organic acid is dependent on its acid dissociation constant $\left(\mathrm{p} K_{\mathrm{a}}\right)$ and the $\mathrm{pH}$ of the environment. Acetic acid has a $\mathrm{p} K_{\mathrm{a}}$ of 4.76 and, at the low $\mathrm{pH}$ normally found in corn silages $(<4)$, a large proportion of it is not dissociated. The undissociated acids can diffuse freely through the microbial plasma membrane, dissociate in the neutral $\mathrm{pH}$ of the cytoplasm, and then release protons. These charged ions cannot move back across the membrane; thus, they accumulate in the cell and acidify the cytoplasm, potentially inhibiting glycolysis, preventing active transport, or interfering with signal transduction (Lambert and Stratford, 1999).

\section{CONCLUSIONS}

Overall, inoculation of corn forages with L. buchneri, with or without $P$. pentosaceus resulted in silages with a higher concentration of acetic acid, lower number of fungi, and consequently enhanced stability after exposure to air, although the response varied with location. The addition of $P$. pentosaceus did not reduce the effectiveness of $L$. buchneri. The efficiency of inoculation with $L$. buchneri was monitored by real-time quantitative PCR. Numbers of $L$. buchneri were positively correlated to the content of acetic acid and the aerobic stability of the silages. Our findings also suggest that when evaluating microbial inoculants, studies should include forage from several sites and inoculation should be replicated several times. Further research is warranted to determine what specific factors in forages and the field may affect the effectiveness of added microbial inoculants.

\section{ACKNOWLEDGMENTS}

The authors thank Candice Klingerman, Erin McDonell, and Wenping $\mathrm{Hu}$ from the Dairy Nutrition and Silage Fermentation Laboratory of the University of Delaware for assistance in analytical and statistical analysis. We also thank Jon Hummel and the farm crew of the University of Delaware for planting and harvesting of crops. This study was partially funded by Lallemand Animal Nutrition (Milwaukee, WI).

\section{REFERENCES}

Bolsen, K. K., C. Lin, B. E. Brent, A. M. Feyerherm, J. E. Urban, and W. R. Aimutis. 1992a. Effect of silage additives on the microbial succession and fermentation process of alfalfa and corn silages. J. Dairy Sci. 75:3066-3083.

Bolsen, K. K., R. N. Sonon, B. Dalke, R. Pope, J. G. Riley, and A. Laytimi. 1992b. Evaluation of inoculant and NPN additives: A summary of 26 trials and 65 farm-scale silages. Kansas Agric. Exp. Sta. Rpt. Prog. 651:102.

Chopin, M. C., A. Chopin, and C. Roux. 1976. Definition of bacteriophage groups according to their lytic action on mesophilic lactic streptococci. Appl. Environ. Microbiol. 32:741-746.

Danner, H., M. Holzer, E. Mayrhuber, and R. Braun. 2003. Acetic acid increases stability of silage under aerobic conditions. Appl. Environ. Microbiol. 69:562-567.

Driehuis, F., and S. J. W. H. Oude Elferink. 2000. The impact of the quality of silage on animal health and food safety: A review. Vet. Q. 22:212-216.

Driehuis, F., S. J. W. H. Oude Elferink, and S. F. Spoelstra. 1999. Anaerobic lactic acid degradation during ensiling of whole crop maize inoculated with Lactobacillus buchneri inhibits yeast growth and improves aerobic stability. J. Appl. Microbiol. 87:583-594.

Driehuis, F., S. J. W. H. Oude Elferink, and P. G. Van Wikselaar. 2001. Fermentation characteristics and aerobic stability of grass silage inoculated with Lactobacillus buchneri, with or without homofermentative lactic acid bacteria. Grass Forage Sci. 56:330 343.

Filya, I. 2003. The effect of Lactobacillus buchneri and Lactobacillus plantarum on the fermentation, aerobic stability, and ruminal degradability of low dry matter corn and sorghum silages. J. Dairy Sci. 86:3575-3581.

Kleinschmit, D. H., and L. Kung Jr.. 2006a. The effects of Lactobacillus buchneri 40788 and Pediococcus pentosaceus R1094 on the fermentation of corn silage. J. Dairy Sci. 89:3999-4004.

Kleinschmit, D. H., and L. Kung Jr.. 2006b. A meta-analysis of the effects of Lactobacillus buchneri on the fermentation and aerobic stability of corn, grass and small grain silages. J. Dairy Sci. 89:4005-4013.

Kleinschmit, D. H., R. J. Schmidt, and L. Kung Jr.. 2005. The effects of various antifungal additives on the fermentation and aerobic stability of corn silage. J. Dairy Sci. 88:2130-2139.

Krooneman, J., F. Faber, A. C. Alderkamp, S. J. H. W. Oude Elferink, F. Driehuis, I. Cleenwerk, J. Swings, and J. C. Gottschal. 2002. Lactobacillus diolivorans sp. nov., a 1,2-propanediol-degrading bacterium isolated from aerobically stable maize silage. Int. J. Syst. Evol. Microbiol. 52:639-646.

Kung, L., Jr., and R. E. Muck. 1997. Animal Response to silage additives. Pages 200-210 in Silage: Field to Feedbunk. NRAES-99. NRAES, Ithaca, NY.

Kung, L. Jr., and N. K. Ranjit. 2001. The effect of Lactobacillus buchneri and other additives on the fermentation and aerobic stability of barley silage. J. Dairy Sci. 84:1149-1155.

Lambert, R. J., and M. Stratford. 1999. Weak-acid preservatives: Modelling microbial inhibition and response. J. Appl. Microbiol. 86:157-164. 
Mäyrä-MäKinen, A., and M. Bigret. 1993. Industrial use and production of lactic acid bacteria. Pages 65-96 in Lactic Acid Bacteria. S. Salminen, and A. von Wright, ed. Marcel Dekker, Inc., New York, NY.

McDonald, P., A. R. Henderson, and S. J. E. Heron. 1991. The Biochemistry of Silage. Chalcombe Publ., Marlow, UK.

Moon, N. J. 1983. Inhibition of the growth of acid tolerant yeasts by acetate, lactate and propionate, and their synergistic mixture. J. Appl. Bacteriol. 55:453-460.

Muck, R. E. 2004. Effects of corn silage inoculants on aerobic stability. Trans. ASAE 47:1011-1016.

Muck, R. E., and J. T. Dickerson. 1988. Storage temperature effects on proteolysis in alfalfa silage. Trans. ASAE 31:1005-1009.

Nelson, N. 1944. A photometric adaptation of the Somogyi method for the determination of glucose. J. Biol. Chem. 153:375-380.

Oude Elferink, S. J. W. H., J. Krooneman, J. C. Gottschal, S. F. Spoestra, F. Faber, and F. Driehuis. 2001. Anaerobic conversion of lactic acid to acetic acid and 1,2-propanediol by Lactobacillus buchneri. Appl. Environ. Microbiol. 67:125-132.

Pahlow, G., R. E. Muck, F. Driehuis, S. J. W. H. Oude Elferink, and S. F. Spoelstra. 2003. Microbiology of ensiling. Pages 31-95 in Silage Science and Technology. American Society of Agronomy, Madison, WI.

Pitt, R. E., and R. Y. Leibensperger. 1987. The effectiveness of silage inoculants: A systems approach. Agric. Syst. 25:27-49.

Ranjit, N. K., and L. Kung Jr.. 2000. The effect of Lactobacillus buchneri, Lactobacillus plantarum, or a chemical preservative on the fermentation and aerobic stability of corn silage. J. Dairy Sci $83: 526-535$

Ranjit, N. K., C. C. Taylor, and L. Kung Jr.. 2002. Effect of Lactobacillus buchneri 40788 on the fermentation, aerobic stability, and nutritive value of maize silage. Grass Forage Sci. 57:1-9.

SAS Institute. 1998. SAS User's Guide: Statistics. Version 7 ed. SAS Inst. Inc., Cary, NC.

Schmidt, R. J., M. G. Emara, and L. Kung Jr.. 2008. The use of a quantitative real-time polymerase chain reaction assay for identification and enumeration of Lactobacillus buchneri in silages. J. Appl. Microbiol. 105:920-929.

Weatherburn, M. W. 1967. Phenol-hypochlorite reaction for determinations of ammonia. Anal. Chem. 39:971-974.

Weinberg, Z. G., G. Ashbell, Y. Hen, and A. Azrieli. 1993. The effect of applying lactic acid bacteria on the aerobic stability of silages. J. Appl. Bacteriol. 75:512-518.

Weinberg, Z. G., G. Ashbell, Y. Hen, A. Azrieli, G. Szakacs, and I. Filya. 2002. Ensiling whole-crop wheat and corn in large containers with Lactobacillus plantarum and Lactobacillus buchneri. J. Ind. Microbiol. Biotechnol. 28:7-11.

Woolford, M. K. 1990. The detrimental effects of air in silage. J. Appl. Bacteriol. 68:101-116.

Wyss, U. 2003. Influence de différerentes variétés de maïs sur la stabilité aérobie de l'ensilage. Rev. Suisse Agric. 35:11-15. 